\title{
Empirical calibration of climate policy using corporate solvency: a case study of the UK's carbon price support
}

\author{
Ben Caldecott ${ }^{a b} \&$ Gerard Dericks ${ }^{a}$
}

\section{Abstract}

Emission reductions improve the chances that dangerous anthropogenic climate change will be averted, but could also cause some firms financial distress. Corporate failures, especially if they are unnecessary, add to the social cost of abatement. This paper proposes using measures of corporate solvency as an objective tool for policymakers to calibrate the optimal stringency of climate change policies, so that they can deliver the least loss of corporate solvency for a given level of emission reductions. We demonstrate this approach to a case study of the UK's Carbon Price Support (a carbon tax). We find that the corporate solvency of energy-intensive industries was stable subsequent to its introduction, and therefore that available evidence did not support its later weakening.

\section{Policy Relevance Statement}

This paper is of interest to a wide range of actors, including policymakers at regional, national, and international levels across many different departments and ministries, from environment and energy through to economics and finance. It speaks to four important topics. First, how to minimise the stranded assets and social costs associated with delivering decarbonisation. Second, how to make climate policies as objective as possible, as well as transparent, so that decisions are aligned with emissions targets

\footnotetext{
a Smith School of Enterprise and the Environment, University of Oxford.

${ }^{b}$ Corresponding author. E-mail: ben.caldecott@smithschool.ox.ac.uk. Tel: +44 7885611444.
} 
and that assumptions underpinning decisions are clearly communicated to markets. Third, providing mechanisms that are potentially robust to likely lobbying from fossil fuel interests. Fourth and more speculatively, building on nascent interest from central banks and financial regulators in climate change topics and exploring the potential to collaborate with or learn from this important community.

Keywords - Climate Change Policy, Stranded Assets, Policy Calibration, Corporate Solvency, Altman's Z-Score

Acknowledgements - This research project would not have been possible without grants from the Generation Foundation and the KR Foundation. The authors would like to acknowledge this support and also to thank the reviewers of previous drafts of this paper.

\section{Intro}

Emission reductions improve the chances that dangerous anthropogenic climate change will be averted, but could also cause some firms financial distress. Corporate failures, especially if they are unnecessary, add to the social cost of abatement. At present, policymakers do not have a means to accurately and impartially gauge the impact of climate policies on corporate solvency. If they did, policymakers could optimise climate policy so that it delivered the least loss of corporate solvency for any given level of emissions reduction.

Here we propose that metrics of corporate solvency be used for this propose. Such measures could act as an objective tool for policymakers. In particular, solvency metrics could be used to empirically calibrate the optimal stringency of climate policies. They could also be used as 
a way to determine the generosity of any industrial compensation to address losses to corporate solvency.

Financial statistics are currently used in this way to calibrate many other areas of government policy. For instance, policymakers currently monitor and regulate certain aspects of corporate solvency in the financial industry (such as capital reserve requirements) in order to reduce the risk of bankruptcy while maintaining profitability. Similarly central banks also consult economic statistics when determining monetary policy.

The fundamental goal of climate policy is to incentivize emissions reductions and the transition to lower-carbon processes and technologies. When firms face new costs related to reducing carbon emissions it is expected that they will suffer some loss of financial condition as they restructure their businesses to minimize these (Requate \& Unold, 2003; Demailly \& Quirion, 2006). However, if the firm becomes bankrupt as a result of such policies, not only will this restructuring not occur - possibly causing high-emitting industries to expand in less constrained jurisdictions (carbon leakage) - but social value can also be permanently destroyed in the form of; the dissolution of organizational capital, deadweight losses paid to liquidators, and the incurrence of costs on unemployed workers.

For example, in a meta-analysis of past studies on the cost to investors of corporate bankruptcy, Branch (2002) estimates that $12-20 \%$ of the firm's original value is lost in the liquidation process. Similar average losses to firm value of $11 \%$ to $17 \%$ and $10 \%$ to $20 \%$ were estimated by Altman (1984) and Andrade \& Kaplan (1998), respectively. Examining the human capital loss associated with employer bankruptcy, Graham, Kim, Li, \& Jiaping (2013) find that former employees lost $30 \%$ of pre-bankruptcy wages for at least five years after bankruptcy, and that the present value of all employee wage losses amounted to $29 \%$ to $49 \%$ of the average prebankruptcy market value of the firm. Other research into the loss of employee earnings has 
found similarly persistent and large effects such as Couch \& Placzek (2010): 32\%; Jacobson, LaLonde, \& Sullivan (1993): 25\%; and Fallick (1996): at least 14\%. Finally, there is the further risk that a sudden industry-wide loss of solvency in affected industries could incite a wider financial panic (Krause, Bach, \& Koomey, 1989; Caldecott, 2011; Carney, 2015).

Nevertheless, an excessively lenient climate policy with low future carbon price expectations could fail to restrain industry from investments in long-lived carbon-intensive infrastructure that could become stranded, and therefore potentially induce the need for a more rapid and expensive industrial transition in order to meet fixed climate change goals. An ideal solvency trajectory for firms affected by climate change policy would therefore cause corporate solvency to initially decline - approaching but not exceeding 'distressed' levels - and then gradually improve to a new 'steady state' once the low-carbon transition had been achieved, at which point the carbon-limiting regulation would continue. If any compensation was provided to industry to help offset reductions in solvency, these would also then be gradually phased-out. This sequence is depicted by the U-shaped solvency trajectory in Figure 1 below.

\section{[INSERT FIGURE 1]}

Due to the discrete social costs associated with the threshold of bankruptcy, this discontinuity represents the fundamental performance criterion on which to base the adjustment of environmental policy. An additional advantage of using financial statistics to calibrate environmental policies generally is the fact that this process would be comparatively objective. At present, there is considerable potential for industrial outcry and political lobbying to influence policy resulting in negative social consequences. Indeed even when the need for regulatory change has been obvious, policymakers often struggle to enact needed reforms, and even when successful, often fail to do so in a timely manner. For instance, it is widely

1 An example of this may be the 19 highly-carbon intensive coal plants currently at various stages of planning in the EU (Mathiesen, 2014). 
acknowledged that EU Emissions Trading Scheme (EU ETS) has failed to deliver a price signal consistent with intentions since at least the beginning of 2012, when price levels stabilised below $5 € /$ ton $\mathrm{CO}_{2.2}$ However, a plan to redress this situation was not approved by the EU Commission until 2014, and this plan is not due to be implemented until 2021. This situation has led to calls for an overhaul of the EU ETS governance structure (Grosjean, Acworth, Flachsland, \& Marschinski, 2016). By contrast, a climate change policy based on corporate solvency could be adjusted relatively mechanically at each financial reporting period, and would be automatically sensitive to variations in the business cycle. 3

The remainder of this paper applies this climate policy calibration framework to a case study of one of the most recent and significant additions to climate change legislation: the United Kingdom's Carbon Price Support (CPS). The CPS was introduced on April $1^{\text {st }} 2013$ as an an added surcharge to the Climate Change Levy (CCL): a pre-existing tax on the use of energy delivered to non-domestic users in the United Kingdom. The CPS is calculated based on a topup payment to the price level of EU ETS permits. Although the CPS was slated to rise incrementally to $£ 30$ per ton $\mathrm{CO}_{2}$ in 2020 , scheduled price increases were frozen in 2015 (see Table 1 for a complete history). When the CPS is combined with the price of EU ETS permits it is known as the Carbon Price Floor (CPF). Although CCL rates are paid directly by businesses for their energy supply, the CPS is paid by owners of energy generating stations, and so may indirectly increase industrial electricity costs. 4 The CPS is a unilateral tax that the UK enacted without the participation of any other EU member state in response to the aforementioned chronic failure of the EU ETS; and a desire by the UK to meet its commitments

\footnotetext{
2 In 2003 (well before the EU Emissions Trading Scheme's launch in 2005) the UK government regulator Ofgem expected price levels to have risen to 33-49€/ton by 2010 (Ofgem, 2003), and the lowest price scenario for EU ETS permits forecasted for 2012 by McKinsey \& Co was $20 € /$ ton $\mathrm{CO}_{2}$ (UBS, 2003).

3 Sensitivity to the business cycle would depend on the timeliness of financial reporting.

4 There are exemptions, mainly for small generators $(<2 \mathrm{WM})$ and plants that use coal slurry.
} 
to; generate $15 \%$ of electricity from renewable sources by 2020 , and to reduce greenhouse gas emissions by $80 \%$ of 1990 levels by 2050 .

\section{[INSERT TABLE 1]}

The CPS is a relevant case study for applying our policy calibration methodology because it is one of the world's most recent and substantial carbon taxes and is administered in a large developed economy with good financial micro-data. Within industry it has also been widely claimed that the CPS has had a significant effect on the production costs of manufacturers. 5 The EEF (the UK Manufacturers' Association) for instance has said that the Carbon Price Support added between five and ten per cent to the energy bills of energy-intensive companies, making them less competitive on the international stage (Shankleman, 2014), and that energy prices and green taxes are worrying the industry more than any other issue (Groom, 2014). Given these characteristics, other internationally competitive manufacturing nations trialling carbon pricing may find the UK's experience of the CPS applicable to their own situations.

This paper proceeds as follows; Section 2 conducts a literature review on how optimal climate change policy is currently modelled as well as the economic effects of climate policy generally. In Section 3 we outline how we measure corporate solvency and provide an exposition of the data used in this study. Section 4 presents the results on the effects of the CPS on the corporate solvency of energy-intensive firms, Section 5 provides a discussion of these results, and Section 6 concludes.

5 Energy price increases are most strongly felt in manufacturing, as energy expenditures are larger here than in any other industrial sector. However, within manufacturing there are a number of industries whose products are exceptionally energy-intensive. We examine the effect of the CPS on these sectors specifically. 


\section{Literature Review}

The idea of using objective financial statistics to calibrate the optimal strictness of policy measures is not new. It is perhaps most prevalent in the views that fiscal and monetary policy can be used to smooth the business cycle. With regard to monetary policy, central banks continuously scan financial and economic statistics to moderate lending strategies. In the case of climate change, models for optimal policy determination have been based on cost-benefit assumptions and either analyse which policy instrument would be best - for example a tax versus cap and trade permits (Nordhaus, 1993; Mandell, 2005; Wirl, 2012; Strand, 2013), or prescribe an optimal level of stringency and timing for a particular policy based on historical market dynamics and a specified emissions goal (Roughgarden \& Schneider, 1999; Golosov, Hassler, Krusell, \& Tsyvinski, 2014). Refinements of these models explore how the optimality of this policy is influenced by relaxing certain assumptions, such as that the damages anticipated from climate change are uncertain (Nordhaus, 1994; Pizer, 1999; Baker \& Shittu, 2008), that abatement technologies improve over time (Goulder \& Mathai, 2000; Requate \& von Dollen, 2008; Gerlagh, Kverndokk, \& Rosendahl, 2009; Weber \& Neuhoff, 2010; Ploeg \& Withagen, 2014), or that abatement policies are nationally unilateral (Felder \& Rutherford, 1993; Bohringer, Carbone, \& Rutherford, 2012; Eichener \& Pethig; 2013). However, even in the most realistic scenarios it is only by assuming away actual uncertainties surrounding the evolutions of the business cycle and firm cost functions that these studies are able to calculate an optimal stringency of climate policy. These assumptions are of course artifice. In the real world the progression of the economy and technology are unknowns (see for instance Lachmann, 1977[1959] and Hayek, 1978), and it would therefore be more fitting to inquire how policy could be adjusted in order to adapt to the way in which these uncertainties unfold. Some previous research has hinted at these problems such as van den Bergh (2004) which rejects quantitative cost-benefit frameworks for assessing climate change policies, arguing that 
the complexity of climate change demands a qualitative analytical approach. In our view the method of empirically calibrating climate policy proposed here synthesises the strengths of both these approaches, on the one hand objectively balancing costs and benefits, and on the other explicitly taking into account real world uncertainties.

Although the effects of carbon regulation on certain aspects of economic performance are well documented (see for instance Zhang \& Baranzini, 2004; Abrell, Ndoye Faye, \& Zachmann, 2011; Yu, 2011; Zhao, 2011; Chan, Li, \& Zhang, 2013), no previous studies specifically investigating the effect of environmental regulation on corporate solvency were found. Indeed, this may be the first paper to explicitly suggest that indicators of financial performance be used to continuously calibrate the stringency of environmental regulation generally. Previous research into this issue has instead focused on one-time cost-benefit analyses of a particular policy (see Hahn, 2000 for an overview), and then subsequently produced normative conclusions about the desirability of this policy from these.

Nor was it possible to identify previous research on general economic effects attributable to the CPS specifically.6 To date, empirical economic analyses of carbon taxes in the UK have focused on the Climate Change Levy (CCL) which began in 2001. Early research on this tax by the industry lobby group 'The Federation of Small Businesses' found that, net of various compensatory dispensations granted simultaneously, the CCL made $30 \%$ of Small and Medium-sized Enterprises financially worse off, with the primary losers involved in plastics processing, hospitality, and retailing (2002). Another survey-based study by industry found that $42 \%$ of professionals in the energy industry felt that the CCL had caused a net increase in business costs (London Electricity, 2002). By contrast, later academic research by Martin, de Preux, and Wagner (2014) analysed the effects of the CCL by employing an instrumental

6 Although one paper (Luan \& Lo, 2016) was found which estimated theoretical power plant LCOE increases due to the CPS. 
variable for CCL incidence on microdata of firm performance. They found that, although the CCL had a strong negative impact on the energy intensity of production and electricity use, no statistically significant economic effects were observed with respect to; firm revenue, employment, or plant exit from the UK. The disjoint observed in this case between the extent of industrial outcry on the one hand, and the lack of demonstrable financial harm on the other, may reflect an intrinsic bias in corporate responses to environmental regulation generally.

\section{Methodology and Data}

This study measures corporate solvency by constructing Altman's Z-Scores produced with financial data from energy intensive firms in the EU's 5 main economies. Altman (1968) was among the first to put forward a quantitative model to predict corporate bankruptcy using financial data, and his various Z-Score coefficients (for different types of firms) have been widely applied in industry and are regarded in academic circles as a research standard. The most recently published (Altman, 1983) Z-Score coefficients for private manufacturing firms are reproduced below. The combined scores of these coefficients predict the likelihood of default, with higher scores indicating higher solvency.

$\mathbf{Z}-$ Score $=0.717 \mathbf{X}_{\mathbf{1}}+0.847 \mathbf{X}_{\mathbf{2}}+3.107 \mathbf{X}_{\mathbf{3}}+0.420 \mathbf{X}_{\mathbf{4}}+0.998 \mathbf{X}_{\mathbf{5}}$

where;

$\mathbf{X}_{\mathbf{1}}=$ Working Capital/Total Assets

$\mathbf{X}_{\mathbf{2}}=$ Retained Earnings/Total Assets

$\mathbf{X}_{\mathbf{3}}=$ Earnings Before Interest and Taxes/Total Assets

$\mathbf{X}_{4}=$ Book Value of Equity/Total Liabilities

$\mathbf{X}_{\mathbf{5}}=$ Sales $/$ Total Assets 
Although Altman's Z-score was originally developed as a tool to predict future default, like this study, previous research has used comparisons of Altman's Z-Scores over successive years to monitor firm condition and alert firm management of the need to adjust strategy and operations (Sauer, 2002). Altman (2002) himself also advocates that the use of his Z-Scores be extended from bankruptcy prediction to the measurement of corporate financial risk generally. Consistent with this view, Platt \& Platt (1991) also find that Z-score profiles for failing businesses often exhibit a consistent downward trend as they approach bankruptcy.

A number of other models exist for predicting bankruptcy, perhaps the most notable of these used on UK firms is Taffler's Z (Taffler, 1983). However, Taffler's Z would not have been an ideal metric for this study as it is constructed from listed firms only and its additional data requirements would have reduced our sample size to statistically trivial levels. Since the most recently publicized Altman Z-Score coefficients were constructed from private US manufacturing firms and are now dated7, in order to better fit our sample this study produces updated Altman Z-Score coefficients derived from energy-intensive firms in the EU.

Discriminant Analysis is the statistical technique used by Altman to classify firms as either solvent or bankrupt. In the first phase of Discriminant Analysis, a sample of firms is taken whose subsequent bankruptcy status is known, and their characteristics are used to calculate ZScore coefficients. In the second phase, these coefficients are applied to the original data in order to classify these firms into fitted 'solvent' or 'bankrupt' statuses. Then the 'actual statuses' and 'fitted statuses' of the same firms are compared, and Z-Score thresholds for expected solvency and bankruptcy are determined by the values beyond which all 'actual' bankruptcy statuses of firms have the correct 'fitted' status. In the third phase, these Z-Score coefficients are now applied to the characteristics of new observations with an unknown grouping.

7 More recent Altman's Z-scores were identified such as Appiah and Abor (2009), but these failed to be both derived from EU firms and the private manufacturing sector. 
Observations with estimated Z-Scores within a solvency or bankruptcy threshold are deemed to have that status. If estimated Z-Scores are between these thresholds, they are said to belong to a 'grey area' and to have indeterminate group status.

Following this methodology our analysis consists of first producing updated Altman's Z-Score coefficients based on the financial condition and bankruptcy status of private energy-intensive firms in the UK, Germany, France, Italy, and Spain. These advanced economies were chosen as it was thought that firms in these countries would be the most comparable to those in UK, having similar characteristics, such as technology and management practices. Firms were deemed to be 'energy-intensive' (and therefore included in the sample) if the European Commission defined them as such according to their primary SIC codes (see Appendix). In order to calculate the Altman Z-Score coefficients, financial data for only the most recent year available between 2000-2014 was collected on active and bankrupt firms from Bureau Van Dyke's Orbis Database. All firms in energy-intensive industries which could be identified as 'retail or wholesale trading' (and therefore not actually manufacturing firms), were removed. 8 Descriptive statistics presented in Table 2 below show the resulting dataset of 6,777 active firms and 177 bankrupt firms.

\section{[INSERT TABLE 2]}

Using our sample of active and bankrupt firms, a Discriminant Analysis of bankruptcy was run against the variables $\mathrm{X}_{1}-\mathrm{X}_{5}$ in Equation (1)9, producing the coefficients necessary to calculate Altman's Z-Score estimates.

\footnotetext{
${ }_{8}$ Orbis classifies firms involved solely in the retail and wholesale trade of energy-intensive goods as in the same industry as those firms involved in manufacture. For our purposes this is an erroneous classification.

9 There are two differences between our methodology and Altman's. These are that the Retained Earnings variable in $\mathrm{X}_{2}$ and the Book Value of Equity variable in $\mathrm{X}_{4}$ is proxied by the related variable 'Shareholder Funds' due to lack of data.
} 
Using these five coefficients we next calculate Altman Z-Scores for a sample of energyintensive firms operating in 2012 and 2013 in the UK (affected by the CPS), and Germany, France, Italy, and Spain (not affected by the CPS). These firms were also collected from Bureau Van Dyke's Orbis database. This exercise produced an initial sample of 16,223 firms. Internet research was then conducted in order to remove firms which were; (i) involved solely in the retail and wholesale trade of energy-intensive goods rather than their manufacture, (ii) UK firms which had any production facilities outside of Great Britain (including Northern Ireland which was exempt from the CPS), (iii) German, French, Italian, and Spanish firms which had production facilities outside of these same four 'control' countries, and (iv) firms which were listed on a stock exchange 10 . Naturally only firms which had published all required financial data to construct Altman Z-Scores for the 2012 and 2013 financial years were retained. This produced a sample of 463 firms, 74 of which were UK based.

\section{[INSERT TABLE 3]}

Rather than use our estimated Z-Score to predict bankruptcy, in the next stage of the analysis we use the Z-Scores to compare levels of corporate solvency between those firms affected and not affected by the CPS.11 In particular, we compare the Z-Scores of firms in the UK and outside the UK for the 2013 fiscal year in order to test whether UK firms had relatively lower solvency, and also by comparing the Z-Scores of UK firms between 2012 and 2013: the year before, and of, the CPS's implementation. This comparison was done by using a KolmogorovSmirnov (K-S) test for differences in the cumulative distribution functions of two variables. The K-S test will indicate whether the treated and control cumulative Z-Score distributions are statistically different from one another, and will also indicate the direction (higher or lower) of

\footnotetext{
10 Listed firms were removed in order to ensure comparability. Researchers use different models and thresholds to categorise the solvency of listed and non-listed firms, and therefore it would not be clear how to integrate them together. In any event, only 6 listed firms remained after the selection criteria i-iii were applied.

11 This is done because we are interested in changes in solvency, not predicting which firms will go bankrupt.
} 
this difference. Note that multiple regression analysis is less appropriate in this case because we are solely interested in determining the comparative financial condition of firms, and not in isolating or quantifying the effect of the CPS. Moreover, unlike regression or a comparison of means 12, a K-S test is non-parametric and distribution-free.

\section{Analysis and Results}

In the first stage of our analysis we calculate the Altman Z-Score coefficients for the energy intensive firms in the five countries in our sample. This exercise yielded the following results;

\section{[INSERT TABLE 4]}

The results in Table 4 show that these five combined factors are a significant determinant of firm bankruptcy. The canonical correlation describes how much discriminating ability a function possesses with the maximum possible value being unity. The coefficients produced by the discriminant analysis are presented in Table 5 below.

\section{[INSERT TABLE 5]}

The negative coefficient for $\mathrm{X}_{2}$ (Retained Earnings) implies that, counter to expectations, increases in the (Shareholder Funds/Total Assets) ratio increases financial distress 13. This adverse result could be due to sampling or modelling issues. In particular, we proxy Retained Earnings with Shareholder Funds. However, there are 85 firms in our sample of 6,777 which have data on Retained Earnings. For these firms the correlation between Altman's original variable for $\mathrm{X}_{2}$ (Retained Earnings/Total Assets) and the proxied variable for $\mathrm{X}_{2}$ (Shareholder Funds/Total Assets) was found to be 0.47 . Given that the coefficient on $\mathrm{X}_{2}$ is close to zero, we

12 Regression analyses yield the same results and these are available from the authors on request.

13 Discriminant Analysis was also run with a random sample stratified by country and industrial sector of 177 solvent firms on the 177 bankrupt firms. However, all coefficients on the five financial ratios from this exercise were unexpectedly negative, suggesting problematic sampling error due to this reduced sample size. 
could also attribute this result to error in our proxy choice for $\mathrm{X}_{2}$. Alternatively companies with relatively high proportions of equity (low leverage) could be suffering from difficulties raising debt due to business problems not captured by the balance sheet.

Using these estimated coefficients we now calculate the Z-Scores for our sample of 463 treated and control firms. Summary statistics of these Z-Scores are presented in Table 6 below.

\section{[INSERT TABLE 6]}

Figure 2 below plots the distributions of the 2013 UK and Non-UK Z-Scores. We test whether the 2013 UK firm Z-Scores are lower than the 2013 Non-UK firms using a K-S test, the results of which are presented in Table 7.

\section{[INSERT FIGURE 2]}

\section{[INSERT TABLE 7]}

Surprisingly, the K-S test finds that in 2013 the UK Z-Scores were in fact significantly greater than the Non-UK Z-Scores with a high level of confidence. This implies that firms under the CPS were in an even stronger financial position than those that were not. A possible explanation for this counterintuitive result may be that economic conditions were generally better in the UK than the Non-UK sample, as evidenced by increases in UK GDP throughout 2013 of $1.73 \%$, versus Germany: $1.06 \%$, France: $0.28 \%$, Italy: $-1.93 \%$, and Spain: $-1.23 \%$ (World Bank Data). Fixed-effects regression analyses in Appendix B also support the conclusion that contemporaneous macroeconomic improvements negated any solvency effect of the CPS.

The lack of an observed change in corporate solvency suggests that the financial position of UK energy-intensive firms was not, net of macroeconomic conditions, heavily impacted by the 
CPS at the end of the 2013 financial year. To further examine this assertion, we compare the 2012 and 2013 Z-Scores for energy-intensive firms in the UK only.

\section{[INSERT FIGURE 3]}

\section{[INSERT TABLE 8]}

Visual inspection confirms the similarity of Z-Score distributions between 2012 and 2013 for firms in the UK-only, and as expected, the K-S test does not reject the null hypothesis of equivalence of the distributions. This result also suggests that the CPS did not put undue financial pressure on the firms most affected by it. Nevertheless, if we examine the 2012 and 2013 UK Z-Score means in Table 5 we see that the average decreased slightly from 1.18 to 1.17. So although there is no statistical difference between the 2012 and 2013 UK Z-Scores, we did measure a small solvency loss.

As a robustness check, we also examine the change in corporate death rates (bankruptcy) for energy-intensive firms in the UK between 2012-2013 in Table 8. Here we find that not only did corporate death rates for these firms not increase between 2012-2013, they in fact fell marginally.

[INSERT TABLE 9]

\section{Discussion}

\subsection{The Effect of the CPS}

We found that; (i) 2013 Z-Scores for energy-intensive firms in the UK are statistically higher than Non-UK Z-Scores, (ii) although corporate solvency for UK energy-intensive firms fell marginally the change was statistically indistinguishable, and (iii) that the death rate of energyintensive firms in the UK in fact decreased between 2012-2013. Therefore, on net, the evidence 
suggests that energy-intensive firms in the UK were not under undue financial strain as a result of the imposition of the CPS. Therefore, we would argue that the industrial outcry raised against the CPS, and UK policymakers' decision to freeze planned price increases in response, was unwarranted.

However, two principle qualifications to this result should be noted. To begin with, there is the obvious criticism that it may take longer than a single financial year for the full effects of the Carbon Price Support to materialise. Nevertheless, previous research that has investigated timevarying effects of environmental regulation on economic outcomes tends to find negative effects in the first year, followed by positive effects in subsequent years (Kozluk \& Zipperer, 2013). While it is almost certainly the case that solvency responses to climate-related legislation develop gradually over a number of years, over even longer timeframes it has been argued by Porter (1991) and Porter \& van der Linde (1995) that properly designed environmental policies can stimulate innovation that may partially or even fully offset the costs of compliance. In addition, it has also been shown by Xepapadeas \& DeZeeuw (1999) and Commins, Lyons, Schiffbauer, \& Tol (2011) that increases in production costs due to carbon prices lead firms to increase average productivity. Hence, long-term negative impacts of a carbon tax might also be less than those measured over the shorter-term, and potentially even a net positive to firm performance. Finally, this criticism would be easily addressed in practice via the continuous solvency monitoring proposed here.

Another possible criticism against our finding that the CPS did not have a strong negative effect on solvency is that, since the CPS was implemented through the tax system rather than as a contractual arrangement (as in the case of the EU ETS), the repeal and/or amendment of the CPS is a comparatively simple exercise (as turned out to be the case in 2014). Hence, energyintensive firms may have discounted the threat that the CPS posed to their future profitability, and therefore may not have responded as dramatically as they would have if they had believed 
the CPS was credibly a long-term policy (Fankhauser, 2013; Lofgren, Wrake, Hagberg \& Roth, 2014).

In spite of these qualifications, given that the ultimate purpose of this paper is to illustrate the possibility of using corporate solvency to calibrate climate policy generally, and not attribute an effect of the CPS on solvency specifically, we believe that this analysis is still instructive.

\subsection{Solvency Levels and Optimal Policy}

The question of where the optimal solvency threshold should lie is crucial for the practical application of climate policy calibration. For instance, depending on the regulator's particular goals the relevant policy benchmark could be either; (i) an overall average solvency level, (ii) a minimum solvency level for the most financially distressed firm, (iii) or a maximum solvency loss for the most affected firm. Moreover, the policy goal may not just be solvency for affected firms but also their competitiveness, in which case, depending on the regulations faced by international competitors, the optimal lower bound for solvency may need to be raised in Figure 1 from financial distress to some other higher level. The availability and timeliness of financial data will also influence the optimal threshold. Since the financial position of firms may deteriorate between financial reports, it may be prudent to adjust thresholds upwards to add a margin of safety against rapid solvency losses. Of course, it would be equally essential to ensure that firms could not 'game' their financial statements in order to present an artificially dire picture to sympathetic regulators. It may also be the case that within a given emissions target, it may not be possible to maintain the solvency of all affected firms. In such cases the emissions target may need to take precedence over solvency concerns, but nevertheless the use of policy calibration via solvency could still be an efficient way to minimize the bankruptcy losses that may be necessary in order to achieve a desired emissions goal. Future research will no doubt refine this optimal policy threshold. 
Future research may also look to refining the Altman Z-Scores produced above, or compare other methods for producing metrics of corporate solvency, such as conditional probability models. Such research could also quantify and operationalize the 'optimal' trajectory of corporate solvency depicted in Figure 1 according to specific industries, industrial policies, macroeconomic conditions, financial reporting regimes, and climate change targets. Historical instances of other significant environmental regulation such as the sulfur dioxide cap \& trade program in the US or automobile emissions standards could also be evaluated from the standpoint of optimal corporate solvency trajectories for affected firms; improving our understanding of the efficiency of these interventions, and highlighting areas of possible improvement for current and future environmental policies.

\section{Conclusion}

This paper has introduced solvency targeting as a means for policymakers to efficiently calibrate the stringency of environmental policies. This technique was applied to the UK's recent Carbon Price Support (CPS) climate policy. Using Altman Z-Scores as a measure of solvency, for energy-intensive firms it was found that; (i) 2013 corporate solvency in the UK was statistically higher than for Non-UK firms, (ii) although corporate solvency for UK energyintensive firms fell marginally between 2012-2013 the change was statistically indistinguishable, and (iii) that the death rate of energy-intensive firms in the UK in fact decreased between over the same period. Therefore, on net the evidence supports the conclusion that energy-intensive firms in the UK were not under inordinate financial strain as a result of the CPS, and therefore that the subsequent postponement of planned CPS price increases was unjustified. In order to meet now deferred climate goals and to deal with the possibility of rising economic and climate uncertainty, governments may be compelled to enact increasingly strict carbon-limiting policies. Against this backdrop, the employment of an 
objective tool to calibrate the optimal stringency of climate policy may prove a valuable addition to mitgating the social costs of climate transition. 


\section{References}

Abrell, J., Ndoye Faye, A., \& Zachmann, G. (2011). Assessing the impacts of the EU ETS using firm level data. X Annual Conference of the Euro-Latin Study Network on Integration and Trade.

Altman, E. (1968). Discriminant analysis and the prediction corporate bankruptcy. The Journal of Finance, 23(4), 589-609.

Altman, E. (1983). Corporate Financial Distress. New York: Wiley Interscience.

Altman, E. (1984). A Further Empirical Investigation of the Bankruptcy Cost Question. The Journal of Finance, 39(4), 1067-1089.

Altman, E. (2002). Corporate distress prediction models in a turbulent economic and Basel II environment. NYU Working Paper No. S-CDM-02-11.

Andrade, G., \& Kaplan, S. (1998). How costly is finacial (not economic) distress? Evidence from highly leveraged transactions that became distressed. The Journal of Finance, 53(5), 1443-1493.

Appiah, K. O., \& Abor, J. (2009). Predicting corporate failure: some empirical evidence from the UK. Benchmarking: An International Journal, 16(3), 432-444.

Baker, E., \& Shittu, E. (2008). Uncertainty and endogenous technical hcange in climate policy models. Energy Economics, 30(6), 2817-2828.

Bohringer, C., Carbone, J., \& Rutherford, T. (2012). Unilateral climate policy design: Efficiency and equity implications of alternative instruments to reduce carbon leakage. Energy Economics, 34(52), S208-S217.

Branch, B. (2002). The costs of bankruptcy: A review. International Review of Financial Analysis, 11, 39-57.

Caldecott, B. (2011). Why high carbon investment could be the next sub-prime crisis. The Guardian. Retrieved from https://www.theguardian.com

Carney, M. (2015). Breaking the Tragedy of the Horizon - climate change and financial stability speech by Mark Carney. Available from: www.bankofengland.co.uk

Chan, H. S., Li, S., \& Zhang, F. (2013). Firm competitiveness and the European Union emissions trading scheme. Energy Policy, 63, 1056-1064.

Commins, N., Lyons, S., Schiffbauer, M., \& Tol, R. S. J. (2011). Climate Policy and Corporate Behaviour. Energy Journal, 32(4), 51-68.

Couch, K., \& Placzek, D. (2010). Earnings Losses of Displaced Workers Revisited. The American Economic Review, 100(1), 572-589.

Demailly, D., \& Quirion, P. (2006). CO2 abatement, competitiveness and leakage in the European cement industry under the EU ETS: grandfathering versus output-based allocation, Climate Policy, 6(1), 93-113.

Eichener, T., \& Pethig, R. (2013). Flattening the carbon extraction path in unilateral cost-effective action. Journal of Environmental Economics and Management, 66(2), 185-201.

Fallick, B. (1996). A review of the recent empirical lierature on displaced workers. Industrial and Labor Relations Review, 50(1), 5-16.

Fankhauser, S. (2013). Practitioner's guide to a low-carbon economy: lessons from the UK. Climate Policy, 13(3), 345-362.

Felder, S., \& Rutherford, T. (1993). Unilateral CO2 reductions and carbon leakage: The consequences of intl trade in oil and basic minerals. Journal of Environmental Economics and Management, 25(2), 162-176.

Gerlagh, R., Kverndokk, S., \& Rosendahl, K. (2009). Optimal timing of climate change policy: Interaction between carbon taxes and innovation externalities. Environmental Resource Economics, 43, 369-390.

Golosov, M., Hassler, J., Krusell, P., \& Tsyvinski, A. (2014). Optimal taxes on fossil fuel in general equilibrium. Econometrica, 82(1), 41-88.

Goulder, L., \& Mathai, K. (2000). Optimal CO2 abatement in the presence of induced technical change. Journal of Environmental Economics and Management, 39, 1-38.

Graham, J., Kim, H., Li, S., \& Jiaping, Q. (2013). Human Capital Loss in Corporate Bankruptcy. US Census Bureau Center for Economic Studies, Paper No. CES-WP-13-37.

Groom, B. (2014, February 23). Manufacturers warn chancellor over spiralling energy costs. Financial Times. Retrieved from https://www.ft.com 
Grosjean, G., Acworth, W., Flachsland, C., \& Marschinski, R. (2016). After monetary policy, climate policy: is delegation the key to EU ETS reform? Climate Policy, 16(1), 1-25.

Hahn, R. (2000). The impact of economics on environmental policy. Journa of Environmental Economics and Management, 39, 375-399.

Hayek, F. (1978). Competition as Discovery Procedure. Quarterly Journal of Austrian Economics, Summer 2002, 5(2), 9-23.

House of Commons Library. (23 November 2016). The Carbon Price Floor.

Jacobson, L., LaLonde, R., \& Sullivan, D. (1993). Earnings losses of displaced workers. The American Economic Review, 83(4), 685-709.

Kozluk, T., \& Zipperer, V. (2013). Environmental Policies and Productivity Growth: A Critical Review of Empirical Findings. OECD Economics Department Working Papers, No. 1096.

Krause, F., Bach, W., \& Koomey, J., (1989). From Warming Fate to Warming Limit: Benchmarks to a Global Climate Convention. El Cerrito, CA: International Project for Sustainable Energy Paths.

Lachmann, L. (1977 [1959]). Capital, Expectations and the Market Process. Kansas City, Missouri: Sheed, Andrews, and McMeel.

Lofgren, A., Wrake, M., Hagberg, T., and Roth, S. (2014). Why the EU ETS needs reforming: an empirical analysis of the impact on company investments. Climate Policy, 14(5), 537-558.

London Electricity (2002). Climate Change Levy Report.

Luan, T., \& Lo, K. (2016). Effect of carbon price floor on levelised cost of gas-fired generation technology in the UK. World Journal of Engineering and Technology, 4, 66-71.

Mandell, S. (2005). The choice of multiple or single auctions in emissions trading. Climate Policy, 5(1), 97-107.

Martin, R., de Preux, L. B., \& Wagner, U. J. (2014). The Impact of a Carbon Tax on Manufacturing: Evidence from Microdata. Journal of Public Economics, 117, 1-14.

Mathiesen, K. (2014). New coal power stations threat to EU's emissions target. The Guardian.

Nordhaus, W. (1993). Rolling the 'DICE': An optimal transition path for controlling greenhouse gases. Resource and Energy Economics, 15, 27-50.

Nordhaus, W. (1994). Managing the Global Commons. Cambridge: MIT Press.

Ofgem (Nov 2003). Emissions Trading Briefing paper: Information for Ofgem's Environmental Advisory Group.

ONS (2013). Business Demography 2013.

Pizer, W. (1999). The optimal choice of climate change policy in the presence of uncertainty. Resource and Energy Economics, 21, 255-287.

Platt, H., \& Platt, M. (1991). A note on the use of industry-relative ratios in bankruptcy prediction. Journal of Banking \& Finance, 15, 1183-1194.

Ploeg, F., \& Withagen, C. (2014). Growth, renewables, and the optimal carbon tax. International Economic Review, 55(1), 283-311.

Porter, M. (1991). America's Green Strategy. Scientific American, 264(4), 96-168.

Porter, M., \& van der Linde, C. (1995). Toward a new conception of the environment-competitiveness relationship. Journal of Economic Perspectives, 9(4), 97-118.

Requate, T., \& Unold, W. (2003). On the incentives created by policy instruments to adopt advanced abatement technology: will the true ranking please stand up? European economic review(47), 125-146.

Requate, T., \& von Dollen, A. (2008). Environmental Policy and Uncertain Arrival of Future Abatement Technology. The B.E. Journal of Economic Analysis \& Policy, 8(1), 1935-1682.

Roughgarden, T., \& Schneider, S. (1999). Climate change policy: quantifying uncertainties for damages and optimal carbon taxes. Energy Policy, 27, 415-429.

Sauer, T. (2002). How may we predict bankruptcy? Business Credit Selected Topic, 104, 16-17.

Shankleman, J. (2014, May 22). EU approves carbon price compensation for energy intensive firms. Business Green. Retrieved from https://www.businessgreen.com

Strand, J. (2013). Strategic climate policy with offsets and incomplete abatement: Carbon taxes versus cap-and-trade. Journal of Environmental Economics and Management, 66(2), 202-218.

Taffler, R. J. (1983). The assessment of company solvency and performance using a statistical model. Accounting and Business Research, 15(52), 295-308.

The Federation of Small Businesses (2002). The climate change levy: Another cost for small businesses. 
UBS (2003, September). European Emissions Trading Scheme.

van den Bergh, J. (2004). Optimal climate policy is a utopia: from quantitative to qualitative cost-benefit analysis. Ecological Economics, 48, 385-393.

World Bank Data. National GDP growth (annual\%).

Weber, T., \& Neuhoff, K. (2010). Carbon markets and technological innovation. Journal of Environmental Economics and Management, 60(2), 115-132.

Wirl, F. (2012). Global warming: Prices versus quantities from a strategic point of view. Journal of Environmental Economics and Management, 64(2), 217-229.

Xepapadeas, A., \& DeZeeuw, A. (1999). Environmental policy and competitiveness: the Porter hypothesis and the composition of capital. Journal of Environmental Economics and Management, 37(165-182).

Yu, H. (2011). The EU ETS and firm profits: An ex-post analysis for Swedish energy firms. Uppsala University Working Paper, 2.

Zhang, Z., \& Baranzini, A. (2004). What do we know about carbon taxes? An inquiry into their impacts on competitiveness and distribution of income. Energy Policy, 32, 507-518.

Zhao, Y.-H. (2011). The Study of Effect of Carbon Tax on the International Competitiveness of Energyintensive Industries: An Empirical Analysis of OECD 21 Countries, 1992-2008. Energy Procedia, 5, 1291-1302. 


\section{Figures and Tables}

\section{Figure 1: Idealised Solvency Trajectory for Industries Affected by Climate Policy}

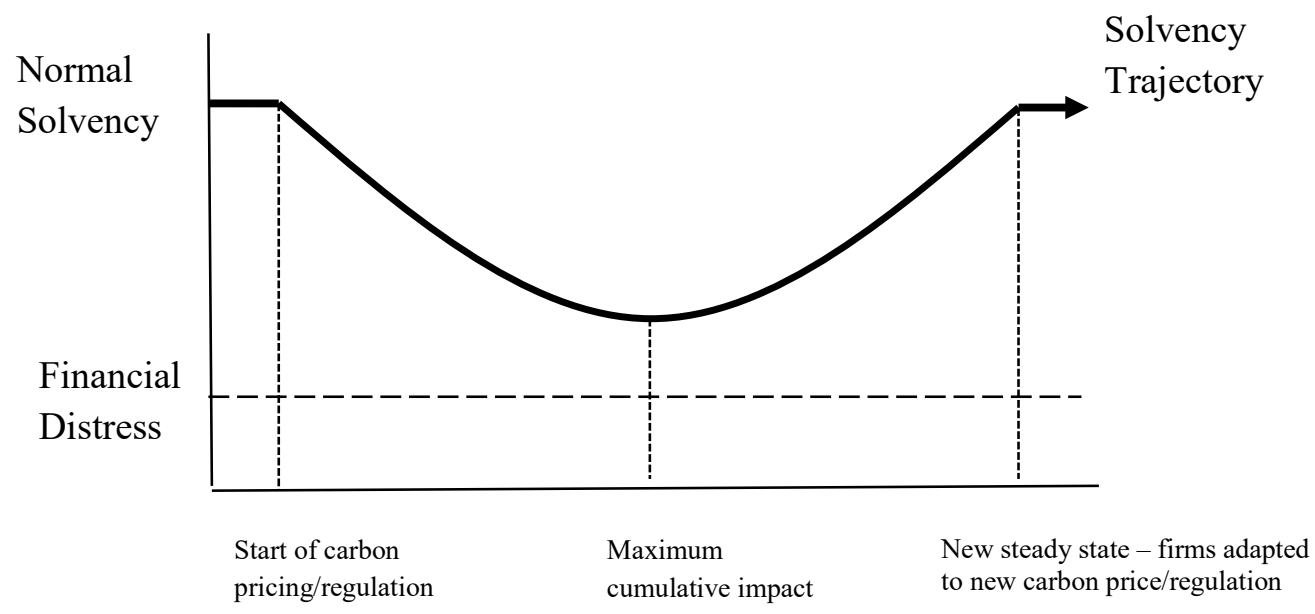

Table 1: UK Carbon Price Support History

\begin{tabular}{|c|c|c|c|c|}
\hline & Ratified & Start & End & Effect \\
\hline $\begin{array}{l}\text { Carbon Price } \\
\text { Support (CPS) } \\
\text { Tax on fossil fuels } \\
\text { used to generate } \\
\text { electricity (Northern } \\
\text { Ireland Exempt) } \\
\end{array}$ & $\begin{array}{l}\text { Mar } 23^{\text {rd }} \\
2011\end{array}$ & Apr $1^{\text {st }} 2013$ & $\begin{array}{l}\text { Apr } 1^{\text {st }} \\
2030\end{array}$ & $\begin{array}{l}£ 4.94 / \text { ton CO2 in } 2013 \text {, rising } \\
£ 9.55 \text { in } 2014, £ 18.08 \text { in } 2015 \text { and } \\
\text { incrementally to } £ 30 \text { in } 2020 \text { and } \\
£ 70 \text { in } 2030\end{array}$ \\
\hline CPS Price Freeze & $\begin{array}{l}\text { Mar } 19^{\text {th }} \\
2014\end{array}$ & Apr $1^{\text {st }} 2014$ & $\begin{array}{l}\text { Apr } 1^{\text {st }} \\
2019\end{array}$ & $\begin{array}{l}\text { Frozen to } £ 18.08 / \text { ton } \mathrm{CO} 2 \text { from } \\
\text { April } 1^{\text {st }} 2015 \text { until } 2020\end{array}$ \\
\hline $\begin{array}{l}\text { CPS Compensation } \\
\text { Scheme }\end{array}$ & $\begin{array}{l}\text { May } 22^{\text {nd }} \\
201414\end{array}$ & $\begin{array}{l}\text { April } 1^{\text {st }} 2015 \\
\text { (is } \\
\text { retroactive) }\end{array}$ & TBD & $\begin{array}{l}\text { Up to } 85 \% \text { of CPS paid returned for } \\
\text { energy-intensive industries }\end{array}$ \\
\hline
\end{tabular}

Source: House of Commons Library (23 November 2016).

14 Ratified by the EU Commission 
Table 2: Discriminant Analysis Energy-Intensive Firms Descriptive Statistics 2000-2014, $£ 000$ 's $(\mathrm{n}=6,777)$

\begin{tabular}{|c|c|c|c|c|}
\hline & Min & Max & Mean & $\begin{array}{l}\text { Standard } \\
\text { deviation }\end{array}$ \\
\hline Working capital & $-212,111$ & $3,477,310$ & 6,326 & 63,762 \\
\hline Shareholder funds & $-152,285$ & $4,225,684$ & 11,798 & 105,597 \\
\hline Earnings Before Interest and Taxes (EBIT) & $-1,786,512$ & 647,452 & -40 & 26,907 \\
\hline Sales & $-1,019$ & $8,706,000$ & 35,741 & 246,621 \\
\hline Total liabilities & -78 & $6,581,976$ & 10,875 & 114,605 \\
\hline Total assets & 0 & $10,066,105$ & 33,639 & 286,154 \\
\hline $\mathbf{X}_{1}=$ Working Capital/Total Assets & -17.36 & 1.00 & 0.26 & 0.42 \\
\hline $\mathbf{X}_{\mathbf{2}}=$ Shareholder Funds/Total Assets & $-6,398.50$ & 1.87 & -1.10 & 79.80 \\
\hline $\mathbf{X}_{\mathbf{3}}=$ Earnings Before Interest and Taxes/Total Assets & -599.39 & 2.82 & -0.14 & 7.79 \\
\hline $\mathbf{X}_{4}=$ Book Value of Equity/Total Liabilities & $-3,252.71$ & $4,568.34$ & 3.98 & 84.08 \\
\hline $\mathbf{X}_{\mathbf{5}}=$ Sales $/$ Total Assets & -1.00 & 354.77 & 1.41 & 5.90 \\
\hline \multicolumn{5}{|c|}{ Number of Observations } \\
\hline UK & & & & 513 \\
\hline Germany & & & & 480 \\
\hline France & & & & 774 \\
\hline Italy & & & & 2,363 \\
\hline Spain & & & & 2,824 \\
\hline
\end{tabular}

Table 3: Summary Statistics UK and Non-UK firms $(n=463)$

\begin{tabular}{|l|l|}
\hline \multicolumn{2}{|c|}{ Number of Observations } \\
\hline Country & 74 \\
\hline UK & 33 \\
\hline Germany & 138 \\
\hline France & 216 \\
\hline Italy & 2 \\
\hline Induin & \\
\hline Chemicals Sector & 156 \\
\hline Metals & 101 \\
\hline Primary & 7 \\
\hline Textiles & 146 \\
\hline Paper & 53 \\
\hline
\end{tabular}


Table 4: Discriminant Analysis Diagnostic Statistics

\begin{tabular}{|l|l|l|l|}
\hline Canonical Correlation & Likelihood Ratio & F-Statistic & Probability \\
\hline 0.1317 & 0.98262 & 24.536 & 0.0000 \\
\hline
\end{tabular}

Table 5: Discriminant Analysis Estimated Coefficients

\begin{tabular}{|l|r|}
\hline $\mathbf{X}_{\mathbf{1}}$ & 0.9677312 \\
\hline $\mathbf{X}_{\mathbf{2}}$ & -0.0472769 \\
\hline $\mathbf{X}_{\mathbf{3}}$ & 0.3463303 \\
\hline $\mathbf{X}_{\mathbf{4}}$ & 0.0632979 \\
\hline $\mathbf{X}_{\mathbf{5}}$ & 0.3756524 \\
\hline
\end{tabular}

Table 6: Altman Z-Score Summary Statistics

\begin{tabular}{|l|r|r|r|r|r|}
\hline & \multicolumn{1}{|c|}{ N } & \multicolumn{1}{c|}{ Min } & \multicolumn{1}{c|}{ Max } & Mean & \multicolumn{1}{c|}{$\begin{array}{c}\text { Standard } \\
\text { Deviation }\end{array}$} \\
\hline Altman's Z-Score 2012 & 463 & -0.15 & 16.52 & 0.93 & 0.92 \\
\hline Altman's Z-Score 2013 & 463 & -0.21 & 20.39 & 0.97 & 1.20 \\
\hline Non-UK Altman's Z-Score 2012 & 389 & -0.15 & 16.52 & 0.89 & 0.97 \\
\hline Non-UK Altman's Z-Score 2013 & 389 & -0.21 & 20.39 & 0.94 & 1.28 \\
\hline UK-only Altman's Z-Score 2012 & 74 & 0.11 & 3.76 & 1.18 & 0.62 \\
\hline UK-only Altman's Z-Score 2013 & 74 & 0.10 & 4.12 & 1.17 & 0.64 \\
\hline
\end{tabular}

Figure 2: UK and Non-UK 2013 Energy-intensive Firm Altman's Z-Score Histograms: $(n=74),(n=389)$

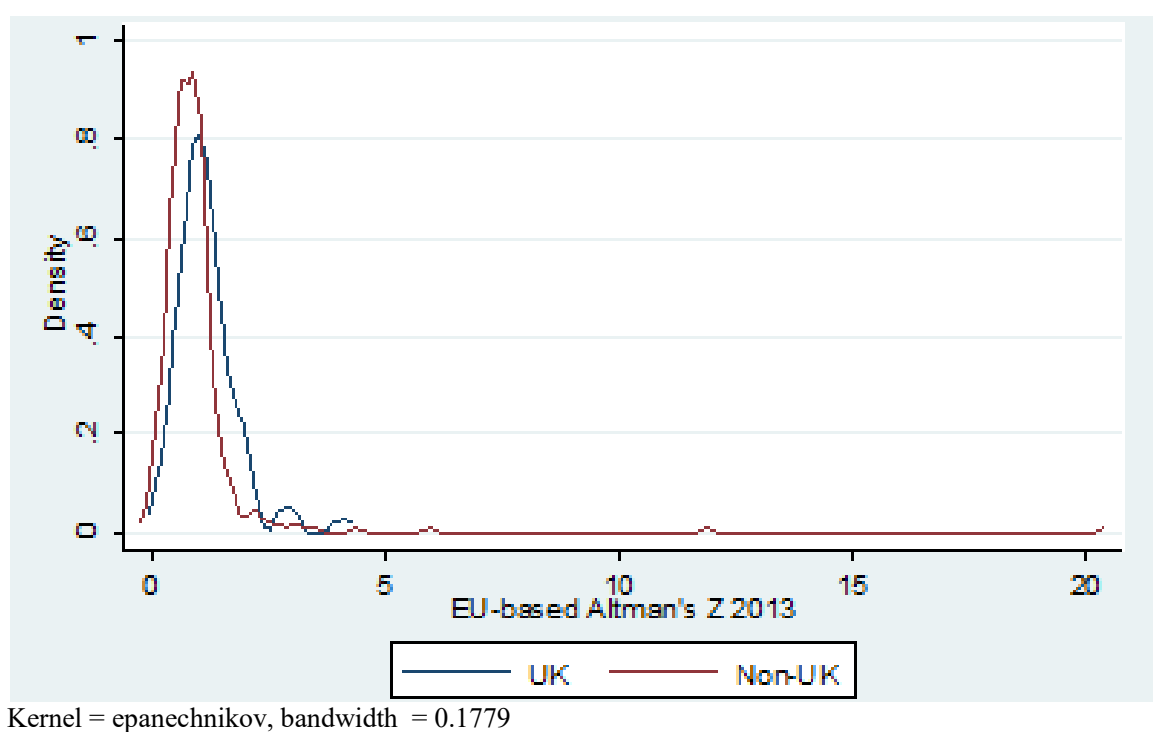


Table 7: Kolmogorov-Smirnov Test for Equality of 2013 UK and Non-UK Z-Score Distributions

\begin{tabular}{|l|l|l|}
\hline & Largest Difference & P-value \\
\hline UK > Non-UK & 0.3001 & 0.000 \\
\hline UK < Non-UK & -0.0103 & 0.987 \\
\hline Combined Test & 0.3001 & 0.000 \\
\hline
\end{tabular}

Figure 3: UK-only 2012 and 2013 Energy-intensive Firm Altman's Z-Score Histograms, $(n=74)$

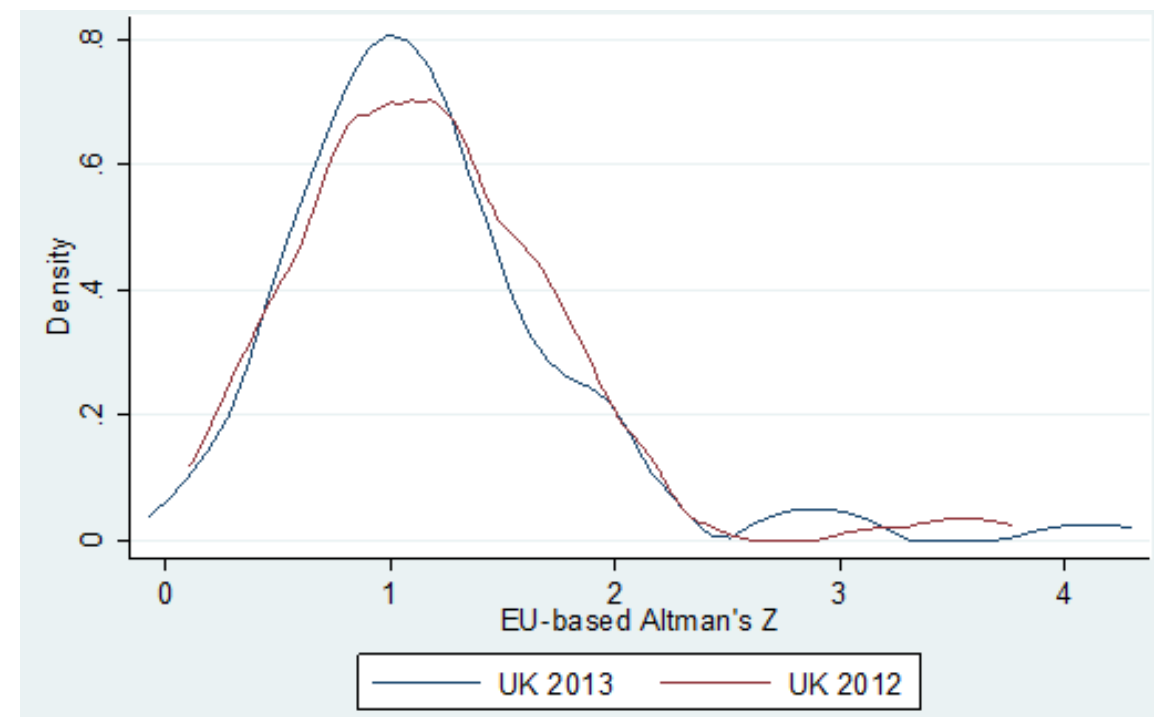

Kernel $=$ epanechnikov, bandwidth $=0.1779$

Table 8: Kolmogorov-Smirnov Test for Equality of UK 2012 and 2013 Z-Score Distributions

\begin{tabular}{|l|l|l|}
\hline & $\begin{array}{l}\text { Largest } \\
\text { Difference }\end{array}$ & P-value \\
\hline $\mathbf{2 0 1 3}>\mathbf{2 0 1 2}$ & 0.0541 & 0.806 \\
\hline $\mathbf{2 0 1 3}<\mathbf{2 0 1 2}$ & -0.0946 & 0.516 \\
\hline Combined Test & 0.0946 & 0.895 \\
\hline
\end{tabular}

Table 9: UK Energy-intensive Firm Business Deaths and Survival 2012 and 2013

\begin{tabular}{|l|r|r|}
\hline & \multicolumn{1}{|c|}{$\mathbf{2 0 1 2}$} & \multicolumn{1}{c|}{$\mathbf{2 0 1 3}$} \\
\hline Deaths & 665 & 690 \\
\hline Survival & 6,190 & 6,410 \\
\hline Death Rate & $10.80 \%$ & $10.76 \%$ \\
\hline
\end{tabular}

Source: ONS Business Demography 2013. Represents annual data based on the 2007 SIC Code conversions of 2003 SIC Code data from Table 9 in the Appendix; ending on November of the stated year. 


\section{Appendix A}

Table 10: European Union Official Energy-intensive Industries

\begin{tabular}{|c|c|c|}
\hline $\begin{array}{l}2003 \text { SIC } \\
\text { Code }\end{array}$ & $\begin{array}{l}2007 \text { SIC } \\
\text { Code }\end{array}$ & Description \\
\hline 27.42 & 24420 & Aluminium production \\
\hline 14.3 & 08910 & Mining of chemical and mineral fertilizer minerals \\
\hline 24.13 & 20130 & Manufacture of other inorganic basic chemicals \\
\hline 27.43 & 24430 & Lead, zinc and tin production \\
\hline 18.1 & 14110 & Manufacture of leather clothes \\
\hline 27.1 & 24100 & Manufacture of basic iron and steel and of ferro-alloys \\
\hline 21.12 & 17120 & Manufacture of paper and paperboard \\
\hline 24.15 & 20150 & Manufacture of fertilizer and nitrogen compounds \\
\hline 27.44 & 24440 & Copper production \\
\hline 24.14 & 20140 & Manufacture of other orga nic basic chemicals \\
\hline 17.11 & 13100 & Preparation and spinning of cotton-type fibres \\
\hline 24.7 & 20600 & Manufacture of man-made fibres \\
\hline 13.1 & 07100 & Mining of iron ores \\
\hline 24.16 & 20160 & $\begin{array}{l}\text { The following sub-sectors within manufacture of plastics } \\
\text { in primary forms } \\
24161039 \text { - Low-density polyethylene } \\
24161035 \text { - Linear low-density polyethylene } \\
24161050 \text { - High-density polyethylene } \\
24165130 \text { - Polypropylene } \\
24163010 \text { - Polyvinyl chloride } \\
24164040 \text { - Polycarbonate }\end{array}$ \\
\hline 21.11 & 17110 & $\begin{array}{l}\text { The following sub-sectors within manufacture of pulp } \\
21111400 \text { - Mechanical Pulp }\end{array}$ \\
\hline
\end{tabular}




\section{Appendix B}

In order to test for the likely causes of a positive and null effect of the CPS on corporate solvency, we employ a fixed-effects regression with respect to each firm's Altman Z-Score between 2012-2013. For control variables we use; Total Assets from the year before the CPS program (ie 2012), industrial sector, and change in macroeconomic variables: GDP, Inflation Rate, Unemployment Rate, and GBP Exchange Rate. Note that for non-UK firms, increases in the ' $\Delta$ Exchange Rate with GBP' variable corresponds to a strengthening of the Euro relative to the pound. For UK firms, the ' $\Delta$ Exchange Rate with GBP' variable is always zero.

Table 12: Fixed Effects Regression Summary Statistics $(n=463)$

\begin{tabular}{|c|c|c|c|c|}
\hline & Min & Max & Mean & Standard Deviation \\
\hline$\Delta$ Altman's Z-Score (2012-2013) & -2.62 & 11.35 & 0.04 & 0.67 \\
\hline Total Assets $2012\left(£^{‘} 000 \mathrm{~s}\right)$ & 8 & $3,060,205$ & 32,019 & 171,384 \\
\hline Country & \multicolumn{4}{|c|}{ Number of Observations } \\
\hline UK & \multicolumn{4}{|c|}{ 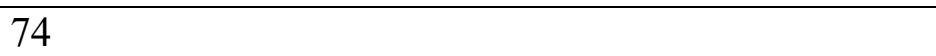 } \\
\hline Germany & \multicolumn{4}{|l|}{33} \\
\hline France & \multicolumn{4}{|l|}{138} \\
\hline Italy & \multicolumn{4}{|l|}{216} \\
\hline Spain & \multicolumn{4}{|l|}{2} \\
\hline \multicolumn{5}{|l|}{ Industry Sector } \\
\hline Chemicals & \multicolumn{4}{|l|}{156} \\
\hline Metals & \multicolumn{4}{|l|}{101} \\
\hline Primary & \multicolumn{4}{|l|}{7} \\
\hline Textiles & \multicolumn{4}{|l|}{146} \\
\hline Paper & \multicolumn{4}{|l|}{53} \\
\hline
\end{tabular}

A step-wise regression is run, sequentially incorporating first just the treatment variable (Carbon Price Support), second the firm specific controls, and finally the macroeconomic controls. We also run an interaction between the Carbon Price Support and Total Assets variable in order to test whether there may be a differential effect with respect to firm size; this might occur, for instance, due to economies of scale in the costs of CPS compliance.

A unique aspect of the Carbon Price Support as opposed to other studies of carbon prices is that approval for a compensation program for energy-intensive industries was not granted until 
over a year after the imposition of the tax (see Table 1) 15. Hence, for the first year of the program the measured effect of the CPS on corporate solvency can be more accurately isolated.

Table 13: Fixed-effects regression by firm 2012-2013, n=463 (74 UK firms)

\begin{tabular}{|c|c|c|c|c|}
\hline VARIABLES & $\begin{array}{c}1) \\
\Delta \text { Altman's Z } \\
\text { Fixed-effects } \\
\end{array}$ & $\begin{array}{c}(2) \\
\Delta \text { Altman's Z } \\
\text { Fixed-effects } \\
\end{array}$ & $\begin{array}{c}3) \\
\Delta \text { Altman's Z } \\
\text { Fixed-effects } \\
\end{array}$ & $\begin{array}{c}(4) \\
\Delta \text { Altman's Z } \\
\text { Fixed-effects } \\
\end{array}$ \\
\hline Carbon Price Support & $\begin{array}{l}-0.0101 \\
(0.0776)\end{array}$ & $\begin{array}{l}-0.0325 \\
(0.0823)\end{array}$ & $\begin{array}{l}-0.237^{*} \\
(0.132)\end{array}$ & $\begin{array}{c}-0.246^{*} \\
(0.137)\end{array}$ \\
\hline Total Assets 2012 ('000s) & & $\begin{array}{c}-2.18 \mathrm{e}-08 \\
(1.79 \mathrm{e}-07)\end{array}$ & $\begin{array}{c}-4.04 \mathrm{e}-08 \\
(1.82 \mathrm{e}-07)\end{array}$ & $\begin{array}{c}-4.96 \mathrm{e}-08 \\
(1.86 \mathrm{e}-07)\end{array}$ \\
\hline Carbon Price Support×Total Assets 2012 & & & & $\begin{array}{c}2.34 \mathrm{e}-07 \\
(9.32 \mathrm{e}-07)\end{array}$ \\
\hline Metals & & $\begin{array}{c}0.000290 \\
(0.0699)\end{array}$ & $\begin{array}{c}0.0570 \\
(0.0869)\end{array}$ & $\begin{array}{c}0.0581 \\
(0.0870)\end{array}$ \\
\hline Primary & & $\begin{array}{l}0.0664 \\
(0.251)\end{array}$ & $\begin{array}{c}-0.00939 \\
(0.260)\end{array}$ & $\begin{array}{c}-0.00972 \\
(0.260)\end{array}$ \\
\hline Textiles & & $\begin{array}{r}0.165 * * * \\
(0.0552)\end{array}$ & $\begin{array}{c}0.211 * * * \\
(0.0802)\end{array}$ & $\begin{array}{c}0.212 * * * \\
(0.0803)\end{array}$ \\
\hline Paper & & $\begin{array}{c}0.0252 \\
(0.0925)\end{array}$ & $\begin{array}{l}0.0508 \\
(0.106)\end{array}$ & $\begin{array}{l}0.0499 \\
(0.106)\end{array}$ \\
\hline$\Delta$ GDP 2012-2013 & & & $\begin{array}{c}0.333 * * \\
(0.152)\end{array}$ & $\begin{array}{c}0.334^{* *} \\
(0.153)\end{array}$ \\
\hline$\Delta$ Interest Rate $2012-2013$ & & & $\begin{array}{c}0.322 \\
(0.201)\end{array}$ & $\begin{array}{c}0.322 \\
(0.201)\end{array}$ \\
\hline$\Delta$ Unemployment Rate 2012-2013 & & & $\begin{array}{l}0.772^{*} \\
(0.422)\end{array}$ & $\begin{array}{l}0.772 * \\
(0.422)\end{array}$ \\
\hline$\Delta$ Exchange rate with GBP $2012-2013$ & & & $\begin{array}{l}-0.867 \\
(1.743)\end{array}$ & $\begin{array}{l}-0.876 \\
(1.745)\end{array}$ \\
\hline $\begin{array}{l}\text { Observations } \\
\text { R-squared }\end{array}$ & $\begin{array}{c}463 \\
0.000\end{array}$ & $\begin{array}{c}463 \\
0.019\end{array}$ & $\begin{array}{c}463 \\
0.034\end{array}$ & $\begin{array}{c}463 \\
0.034\end{array}$ \\
\hline
\end{tabular}

Standard errors in parentheses $* * * \mathrm{p}<0.01, * * \mathrm{p}<0.05, * \mathrm{p}<0.1$

Dependent variable is $\Delta$ Altman's Z-Score

Omitted industry sector dummy is Chemicals

As we can see from Table 10, with industry and macroeconomic controls the Carbon Price

Support exhibits a statistically significant effect in the anticipated direction and at the $10 \%$

level, which can be considered significant given the one-tailed nature of this test. The macroeconomic control variables; ' $\Delta$ GDP' and ' $\Delta$ Exchange Rate' exhibit their theoretically expected signs, whereas the expected sign of ' $\Delta$ Interest Rate' and ' $\Delta$ Unemployment Rate' may 15 The EU ETS for instance used free permit allocations to affect this outcome, and countries imposing carbon taxes such as Finland, Sweden,
and Norway all provided equivalent dispensations to their most vulnerable firms. 
be more ambiguous 16. The control variables which demonstrate statistical significance are the Textile industry dummy, ' $\Delta \mathrm{GDP}$ ', and ' $\Delta$ Unemployment'. Although this analysis supports the conclusion that increases in GDP in the UK relative to control countries is responsible for our finding that there was no solvency loss as a result of the CPS, a notable limitation of these models is the low proportion of the total variance explained.

${ }_{16}$ For instance, net of GDP changes, increases in the ' $\Delta$ Unemployment Rate' variable could in fact be proxying for lower wage costs to the firm 